\title{
Influencing factors of cardiorespiratory fitness in allogeneic stem cell transplant candidates prior to transplantation
}

\author{
Matthias Limbach ${ }^{1} \cdot$ Rea Kuehl $^{1} \cdot$ Peter Dreger $^{2} \cdot$ Thomas Luft $^{2} \cdot$ Friederike Rosenberger $^{1} \cdot$ Nikolaus Kleindienst $^{3}$. \\ Birgit Friedmann-Bette ${ }^{4} \cdot$ Andrea Bondong $^{2} \cdot$ Martin Bohus $^{3} \cdot$ Joachim Wiskemann $^{1}$ (i)
}

Received: 19 February 2020 / Accepted: 20 April 2020 / Published online: 4 May 2020

(C) The Author(s) 2020

\begin{abstract}
Purpose Cardiorespiratory fitness (CRF) seems to be prognostic prior to allogeneic stem cell transplantation (allo-HSCT). Influencing factors of CRF in allo-HSCT candidates have not been studied so far. Aim was to identify potentially influencing factors on CRF.

Methods To assess CRF, a maximal cardiopulmonary exercise test (CPET) was performed on average $2.6 \pm 7.2$ days prior to admission. A regression analysis was conducted, with the following predictors: gender, age, body mass index (BMI), time between last therapy and allo-HSCT ( $\mathrm{t}$-Therapies), number of cardiotoxic therapies (n_Cardiotox), number of transplantations (n_Transplantations), comorbidity index (HCT-CI), hemoglobin level of the last 3 months (area under the curve), and physical activity.

Results A total of 194 patients performed a CPET. $\mathrm{VO}_{2 \text { peak }}$ was significantly reduced compared with reference data. In total, $\mathrm{VO}_{2 \text { peak }}$ was $21.4 \mathrm{ml} / \mathrm{min} / \mathrm{kg}(-27.5 \%, p<0.05)$. Men showed a significant larger percentage difference from reference value ($29.1 \%, p<0.05)$ than women $(-24.4 \%)$. $\mathrm{VO}_{2 \text { peak }}$ was significantly $(p<0.05)$ influenced by age $(\beta=-0.11)$, female gender $(\beta=-3.01)$, BMI $(\beta=-0.44)$, n_Cardiotox $(\beta=-0.73)$, hemoglobin level $(\beta=0.56)$, and physical activity prior to diagnosis $(\beta=0.10)$.
\end{abstract}

Conclusions Our study demonstrates a decreased CRF indicating the potential need of prehabilitative exercise. We revealed some influencing factors on CRF. Those patients could benefit the most from exercise.

Keywords Leukemia $\cdot$ Lymphoma $\cdot$ Risk management $\cdot$ Exercise $\cdot$ Oncology

\section{Introduction}

The number of performed allogeneic hematopoietic stem cell transplantations (allo-HSCT) worldwide has increased over the past decades [1]. This development is related to the extended donor availability and improved transplant techniques

Joachim Wiskemann

joachim.wiskemann@nct-heidelberg.de

1 Department of Medical Oncology, National Center for Tumor Diseases (NCT), Heidelberg University Hospital, Im Neuenheimer Feld 460, 69120 Heidelberg, Germany

2 Department of Medicine V, Heidelberg University Hospital, Heidelberg, Germany

3 Central Institute of Mental Health, Mannheim, Germany

4 Internal Medicine VII (Sports Medicine), Heidelberg University Hospital, Heidelberg, Germany such as reduced intensity conditioning or a better usage of the immunotherapeutic graft-versus-leukemia effect, as well as enhanced supportive measures [2]. As a consequence, mortality rates of allo-HSCT are decreasing constantly, however, remain on a considerable high level [2]. A recent retrospective cohort study demonstrated a decline for non-relapse mortality from 41 to 26\% comparing the years 1993-1997 and 20032007 [3]. Therefore, an accurate risk-benefit stratification is still vital for decision-making in allo-HCT candidates.

Several assessment tools are available for calculating individual patient risk and to define suitable candidates for alloHSCT like the comorbidity index (HCT-CI), the Karnofsky performance status (KPS), or the European Group for Blood and Marrow Transplantation (EBMT) risk score [4-6]. Recently, measurements of cardiac and pulmonary function were introduced to determine patients' physical function and possess prognostic information prior to transplantation [7, 8]. It could be demonstrated that decreased cardio respiratory 
fitness (CRF) values are associated with a lower health-related quality of life, a higher symptom burden, and a higher risk of mortality in patients undergoing HSCT [8]. This has also been shown in other cancer populations $[9,10]$.

Since CRF could be modified by exercise intervention approaches, there is a certain interest to identify factors explaining lower CRF value prior to HSCT. However, the pre-treatment situation in HSCT patients is quite complex, and it is still uncertain on what affects the physical performance prior to HSCT. Initial approaches emphasized that the amount of prior chemotherapies or months of received chemotherapy prior to HSCT might impact CRF [8], but comprehensive data analyses are still missing. Therefore, we aimed to evaluate CRF and its influencing factors in patients immediately prior to allo-HSCT.

\section{Patients and methods}

\section{Setting and patients}

We analyzed baseline data from $n=256$ allo-HSCT patients from the study Physical Exercise Training versus Relaxation in Allogeneic stem cell transplantation (PETRA), a large ongoing two-arm randomized controlled trial (RCT) of exercise intervention. All patients, scheduled for an allo-HSCT at the Heidelberg University Hospital, age $\geq 18$ years and able to understand and follow the study protocol were eligible to be enrolled in the PETRA study. Exclusion criteria were inability to walk or stand, unstable bone lesions, severe neurological deficiencies, severe cardiac or cardiovascular diseases, and severe pulmonary global insufficiency. Cross-sectional data were obtained prior to admission for allo-HSCT. The study has been approved by the ethics committees of the Ethics Committee II of the University of Mannheim (number 2009-349 N-MA) and the Ethics Committee of the University of Heidelberg (number S-021/2011), and is registered at ClinicalTrials.gov (NCT01374399). All patients provide written informed consent.

\section{Determination of CRF}

To assess baseline CRF of the participants, a cardiopulmonary exercise test (CPET) was performed prior to admission. The CPET was conducted on an electronically braked bicycle ergometer (ergoselect 100, Bitz, Germany and Corival, Lode B.V. Medical Technology, Groningen, Netherlands). Gas exchange was measured using a breath by breath system (Ergostik, Geratherm Respiratory, Bad Kissingen, Germany), which was calibrated according to the instructions of the manufacturer before each test. A stepwise incremental protocol was applied, which started at $50 \mathrm{~W}$, and work rate was increased every 2 min by $25 \mathrm{~W}$ until voluntary exhaustion or occurrence of medical reasons. Cadence was kept constant between 60 and $70 \mathrm{rpm}$. A 12-lead electrocardiogram continuously monitored and blood pressure was measured every 2 min during the test. For analysis, we determined $\mathrm{VO}_{2 \text { peak }}$ and the $\mathrm{VO}_{2 \text { peak }}$ in relation to body weight $(\mathrm{ml} / \mathrm{min} / \mathrm{kg})$ referring to the ATS/ACCP recommendations [11]. $\mathrm{VO}_{2 \text { peak }}$ and heart rate were considered the highest 30 s average value during or immediately post-termination CPET. We used the following criteria to determine patients' exhaustion: respiratory exchange ratio (RER) $>1.1$ or HR $>85 \%$ of age predicted maximum.

\section{Potentially influencing factors for CRF}

Additionally, we investigated potentially influencing factors for CRF. Patients were asked to self-report the level of physical activity (walking, cycling, and other sports) in a typical week in the year before diagnosis with a proved questionnaire [12]. The degree of physical activity was operationalized with metabolic equivalent of task (MET). MET hours per week (MET $\times \mathrm{h} /$ week) were calculated by summing the average hours per week spent in walking, cycling, or other sports. The following clinical data prior to allo-HSCT were extracted from the medical records as potentially influencing factors: number of cardiotoxic therapies (n_Cardiotox), number of transplantations (allogeneic and autologous, $\mathrm{n} \_$Transplantations), months between last therapy to alloHSCT (t_Therapies), KPS, remission status, the hematopoietic cell transplantation-specific comorbidity index (HCT-CI), primary hematological malignancies, LVEF (left ventricular ejection fraction), hemoglobin levels, age, gender, and body mass index (BMI). BMI was calculated as body weight divided by square of height in meters. Hemoglobin $(\mathrm{g} / \mathrm{dl})$ level was measured on the day of CPET assessment. Further, we calculated area under the curve values for hemoglobin levels over the last 3 months prior to allo-HSCT (Hemoglobin_auc). The HCT-CI was determined according to guidelines and separated into low to intermediate risk group $(<3)$ and high risk group ( $\geq 3)$ [13].

\section{Statistical analyses}

Baseline clinical and demographic data were reported by descriptive analysis and are reported as mean $\pm \mathrm{SD}$ and range. Differences between measured values of $\mathrm{VO}_{2 \text { peak }}$ and reference values were reported as percent differences. The observed values were compared with reference values by using paired sample $t$ test. Expected individual $\mathrm{VO}_{2 \text { peak }}$ values were calculated by Koch [14] for healthy people of considering age, gender, and BMI distribution. Hemoglobin level over the last 3 months was calculated as area under the curve score using the trapezoidal rule [15]. To identify determinants of CRF prior to allo-HSCT, a multivariate regression analysis was 
conducted. The following independent variables were entered into the regression model simultaneously: age, gender, BMI, $\mathrm{n} \_$Transplantations, n_Cardiotox, t_Therapies, HCT-CI, Hemoglobin_auc, and physical activity. We chose $\mathrm{VO}_{2 \text { peak }}$ as representative value for $\mathrm{CRF}$ and therefore as the dependent variable. In the second regression model, the deviation $\mathrm{VO}_{2 \text { peak }}$ from healthy reference was used as the dependent variable. The level of statistical significance was set at $p<0.05$. Data were analyzed using IBM SPSS v. 22 .

\section{Results}

Five hundred forty-four patients were screened and $n=99$ were ineligible due to exclusion criteria (18.2\%). From $n=$ $445(81.8 \%)$ eligible patients, $n=178(40 \%)$ did not participate. Reasons were $n=94$ (52.8\%) not interested, $n=39$ (21.9\%) due to organizational problems (postponement, no exercise testing capacity available due short notice admission to allo-HSCT), and $n=45$ (25.3\%) because of other reasons. Two hundred sixty-seven patients were included of whom $n=$ 200 participated in CPET. Major reasons for not being able to perform CPET were infections $n=27$ (10.1\%), insufficient blood values $n=7$ (2.6\%), and other medical reasons $n=13$ (4.9\%). Twenty patients (7.5\%) did not participate due to unexpected early inpatient admission or unpredictable date collision. Five of $n=200 \mathrm{VO}_{2 \text { peak }}$ values were not analyzable. One patient did not tolerate the face mask (Fig. 1). No serious adverse events occurred.

Clinical data and demographics of study participants who performed CPET are described in Table 1. Patients had a mean age of $54.1 \pm 11.5$ years. Main diagnosis was acute leukemia (AML, 29.9\%). They were on average $36.6 \pm 47.5$ months after main diagnosis. Mean hemoglobin at the day of CPET testing was $11.7 \pm 1.8(\mathrm{~g} / \mathrm{dl})$ and hemoglobin level during the last 3 months (Hemoglobin_auc) was $11.4 \pm 1.9$ (g/dl). On average, the patients performed the CPET $2.6 \pm 7.2$ days prior to admission. There is a significant association between $\mathrm{n} \_$Transplantations and $\mathrm{n} \_$Cardiotox $(r=0.502, p=<0.001)$. The analysis of number of transplantations in the patients history showed that $n=47(24.2 \%)$ patients received one or more previous transplantations.

\section{CRF in relation to normal values}

$\mathrm{VO}_{2 \text { peak }}$ values were available in 194 patients. All descriptive data of predictors and $\mathrm{VO}_{2 \text { peak }}$ are depicted in Table 1 . Figure 2 shows the deviation of measured $\mathrm{VO}_{2 \text { peak }}$ values and the healthy reference values of CRF.

For the overall sample, $\mathrm{VO}_{2 \text { peak }}$ was on average $21.4 \mathrm{ml} /$ $\mathrm{min} / \mathrm{kg}$, with a value of $22.4 \pm 5.9 \mathrm{ml} / \mathrm{min} / \mathrm{kg}$ for men and $19.3 \pm 4.7 \mathrm{ml} / \mathrm{min} / \mathrm{kg}$ for women. Figure 2 presents the comparison with age- and gender-matched reference values [14].
For the total sample, it was apparent that the $\mathrm{VO}_{2 \text { peak }}$ values were significantly reduced $(-27.5 \pm 20.8 \%, p<0.001)$. The deviation of $\mathrm{VO}_{2 \text { peak }}$ from gender- and age- matched healthy reference values was slightly larger in men $(-29.1 \pm 21.6 \%$, $p<0.001)$ than in women $(-24.4 \pm 18.1 \%, p<0.001)$, with no significant difference between the two groups $(-4.7 \%, p=$ 0.146).

Hemoglobin at the day of CPET was higher in men (11.9 \pm $1.8 \mathrm{~g} / \mathrm{dl})$ than in women $(11.3 \pm 1.5 \mathrm{~g} / \mathrm{dl})$, however there was no statistically difference between men and women (men vs woman $4.7 \%, p=0.766$ ). Hemoglobin values were below the normal range.

Table 2 shows the deviation of $\mathrm{VO}_{2 \text { peak }}$ from healthy reference values, the measured $\mathrm{VO}_{2 \text { peak }}$ values, the amount of cardio toxic agents, and the activity level per week (MET) in the year before diagnosis depending on different age groups. The age group between 46 and 55 years demonstrated the largest deviation from healthy reference values $(-36.6 \% \pm$ 16.7), whereas the eldest ( $60-75$ years) illustrated the smallest deviation $(-11.8 \% \pm 15.9)$. The amount of cardio toxic agents was highest in the youngest age group $(1.9 \pm 1.3)$ with small differences to the other age groups, whereas the oldest participants notably received the least amount $(0.9 \pm 1.9)$.

\section{Factors explaining CRF}

A total of 183 patients could be included in the multiple regression analysis. The analysis reveals age, female gender, BMI, n_Cardiotox, Hemoglobin_auc, and physical activity prior to diagnosis as predictors with a significant influence on $\mathrm{VO}_{2 \text { peak }}$, whereas the HCT-CI, the amount of transplantations (n_Transplantations), and t impact. The $R^{2}$ was $40 \%$ (Table 3 ).

\section{Factors explaining deviation of CRF from normative values}

Regression analysis for the deviation of $\mathrm{VO}_{2 \text { peak }}$ from healthy reference values shows that age, gender, BMI, Hemoglobin_auc, and physical activity prior to diagnosis are significant determinants. The explaining variance is $26 \%$ (Table 4).

\section{Discussion}

Our study demonstrates decreased CRF in allo-HSCT candidates prior to transplantation. Results indicate that patients at higher age, of female gender, with low hemoglobin values, who received cardio toxic treatment prior to allo-HSCT, and have a low physical activity are of risk for lower CRF. Considering gender- and age-matched healthy $\mathrm{VO}_{2 \text { peak }}$ reference values, men as well as patients with a younger age have a 
Fig. 1 Patient flow chart showing the numbers of patients who were available for cardiopulmonary exercise test (CPET)

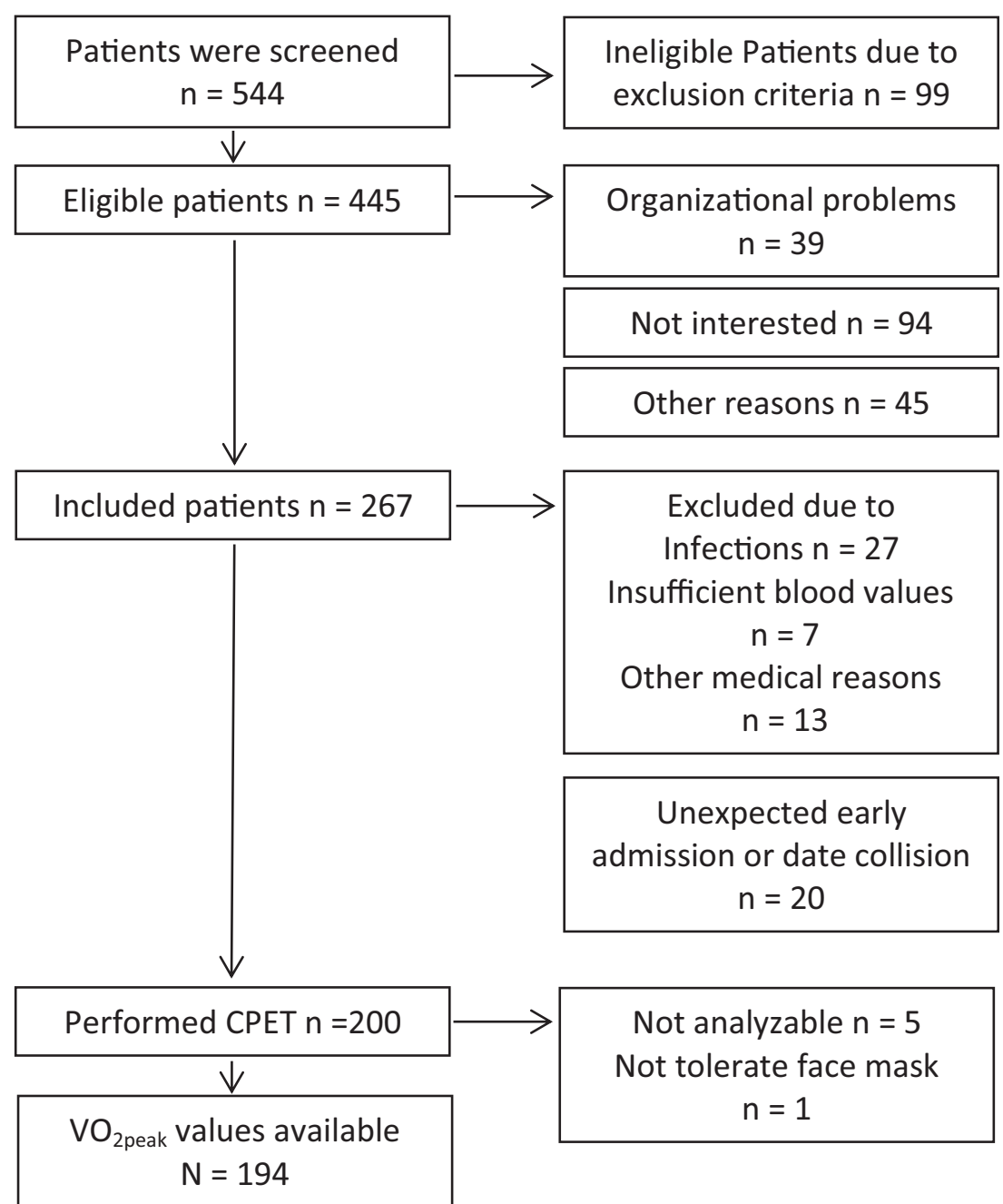

higher risk for lower CRF. A higher BMI and lower physical activity was a significant predictor for low CRF in both regression models.

Reduced physical performance levels prior to HSCT has been found in various studies [7, 8, 16, 17]. However, comprehensive data and analyses procedures are missing to identify patients at risk and to assess the clinical significance of reduced $\mathrm{CRF}$. In comparison with reference values of healthy adults, the $\mathrm{VO}_{2 \text { peak }}$ of our sample was significantly reduced by $-27.5 \%$ which was quite similar to other studies in the field $[7,8]$. This is further in accordance with findings of impaired respiratory and skeletal muscle strength as well as reduced submaximal exercise capacity in patients prior to allo-HSCT [16-18]. In comparison with other severely impacted and treated patient groups like pancreatic cancer patients, the deviation from the healthy reference group was higher [19], whereas breast cancer patients at the same age interestingly showed lower $\mathrm{VO}_{2 \text { peak }}$ values [20].

Since reduced CRF level is associated with poor prognosis after HSCT [8], but on the other hand can be positively modified by exercise therapy $[21,22]$, it is of clinical relevance to detect patient-related predictors in order to identify low CRF patients and to treat them as early as possible in accordance with the prehabilitation approach [23]. Regarding patientrelated predictors, we were able to show that the amount of chemotherapies with cardio toxic ingredients received prior to allo-HSCT is a predictor of low CRF. In light of the fact that $24.2 \%$ of our population received one or more transplantation prior to allo-HSCT, which frequently include cardio toxic agents and affect cardiac function [24, 25] such an observation seems to be plausible [26]. Interestingly, although the number of received cardio toxic treatments could explain variation in CRF, the majority of our population (90\%) showed good LVEF values indicating no major structural impact on the heart muscle. The detection of heart damage after exposure to potentially cardio toxic chemotherapeutic agents is complex and requires various assessment procedures [27] and was not performed within this study. Nevertheless, an explanation for this finding could be that assessments without exercise-induced cardiovascular stress, like a resting echocardiography, are not sensitive enough to detect preliminary heart damage [7]. In addition, it is conceivable that the toxic 
Table 1 Baseline descriptive data

\begin{tabular}{|c|c|c|c|c|}
\hline & Number & Mean & SD & Range \\
\hline Age (year) at diagnosis & 194 & 54.1 & 11.5 & $18-75$ \\
\hline Gender, $n(\%)$ & $194(100)$ & - & - & - \\
\hline Males & $130(67)$ & & & \\
\hline Females & $64(33)$ & & & \\
\hline BMI $\left(\mathrm{kg} / \mathrm{m}^{2}\right)$ & 192 & 26.5 & 5.1 & $17-57$ \\
\hline Diagnosis, $n(\%)$ & $194(100)$ & - & - & - \\
\hline AML & $58(29.9)$ & & & \\
\hline ALL & $10(5.2)$ & & & \\
\hline CLL & $39(20.3)$ & & & \\
\hline MM & $19(9.8)$ & & & \\
\hline CML/MPS & $17(8.7)$ & & & \\
\hline MDS & $16(8.2)$ & & & \\
\hline Other lymphoma & $32(16.3)$ & & & \\
\hline Other & $3(1.6)$ & & & \\
\hline Time from diagnosis to allo-HSCT (month) & 194 & 36.6 & 47.5 & $0-328$ \\
\hline Time between exercise test and admission allo-HSCT (days) & 194 & 2.6 & 7.2 & $0-47$ \\
\hline $\mathrm{HCT}-\mathrm{CI}(n)$ & 184 & 0.9 & 1.5 & $0-8$ \\
\hline$<3$ & 158 & & & \\
\hline$\geq 3$ & 26 & & & \\
\hline Missing & 10 & & & \\
\hline $\operatorname{KPS}(n)$ & 190 & 92.7 & 6.5 & $100-70$ \\
\hline$<90$ & 19 & & & \\
\hline$\geq 90$ & 171 & & & \\
\hline Missing & 4 & & & \\
\hline Hemoglobin day of CPET testing (g/dl) & 194 & 11.7 & 1.8 & $6.8-17.0$ \\
\hline $\operatorname{LVEF}(n)$ & 181 & - & - & - \\
\hline$>55 \%$ & 163 & & & \\
\hline $45-54 \%$ & 14 & & & \\
\hline $30-44 \%$ & 4 & & & \\
\hline$<30 \%$ & 0 & & & \\
\hline Missing & 13 & & & \\
\hline Remission status prior to allo-HCT $(n)$ & 193 & - & - & - \\
\hline $\mathrm{CR}$ & 70 & & & \\
\hline PR & 73 & & & \\
\hline No CR & 46 & & & \\
\hline Unknown & 4 & & & \\
\hline Missing & 1 & & & \\
\hline MET (h/week) & 194 & 7.6 & 14.9 & $0-99.5$ \\
\hline Smokers $(n)$ & 185 & & & \\
\hline Current & 8 & & & \\
\hline Ever & 62 & & & \\
\hline Year before diagnosis & 27 & & & \\
\hline Never & 88 & & & \\
\hline Missing & 7 & & & \\
\hline VO2peak_rel (ml/kg/min) & 194 & 21.4 & 5.7 & $8-41$ \\
\hline VO2peak (1/min) & 194 & 1.71 & 0.5 & $0.7-3.4$ \\
\hline Time since last therapy (month) & 194 & 2.3 & 4.4 & $0-54$ \\
\hline Hemoglobin last 3 months (g/dl) & 192 & 11.4 & 1.9 & $6.5-15.7$ \\
\hline Missing & 2 & & & \\
\hline Amount of cardio toxic agents & 194 & 1.5 & 1.4 & $0-9$ \\
\hline Number of previous transplantations & 194 & 0.3 & 0.6 & $0-3$ \\
\hline
\end{tabular}

$N$, number of patients; $B M I$, body mass index; $H C T-C I$, comorbidity index by Sorror; $K P S$, Karnofsky performance status; $L V E F$, left ventricular ejection fraction; allo- $H C T$, allogeneic stem cell transplantation; $C R$, complete remission; $P R$, partial remission; $A M L$, acute myeloid leukemia; $A L L$, acute lymphocytic leukemia; $M M$, multiple myeloma; $C M L$, chronic myeloid leukemia; $M P S$, myeloproliferative syndrome; $M D S$, myelodysplastic syndrome; $M E T$, metabolic equivalent of task 
Fig. 2 Comparison of measured $\mathrm{VO}_{2 \text { peak }}$ values with gender- and age-matched healthy reference $\mathrm{VO}_{2 \text { peak }}$ values in total, men and women. * = significant difference to measured $\mathrm{VO}_{2 \text { peak }}$ and reference values $p<0.005$

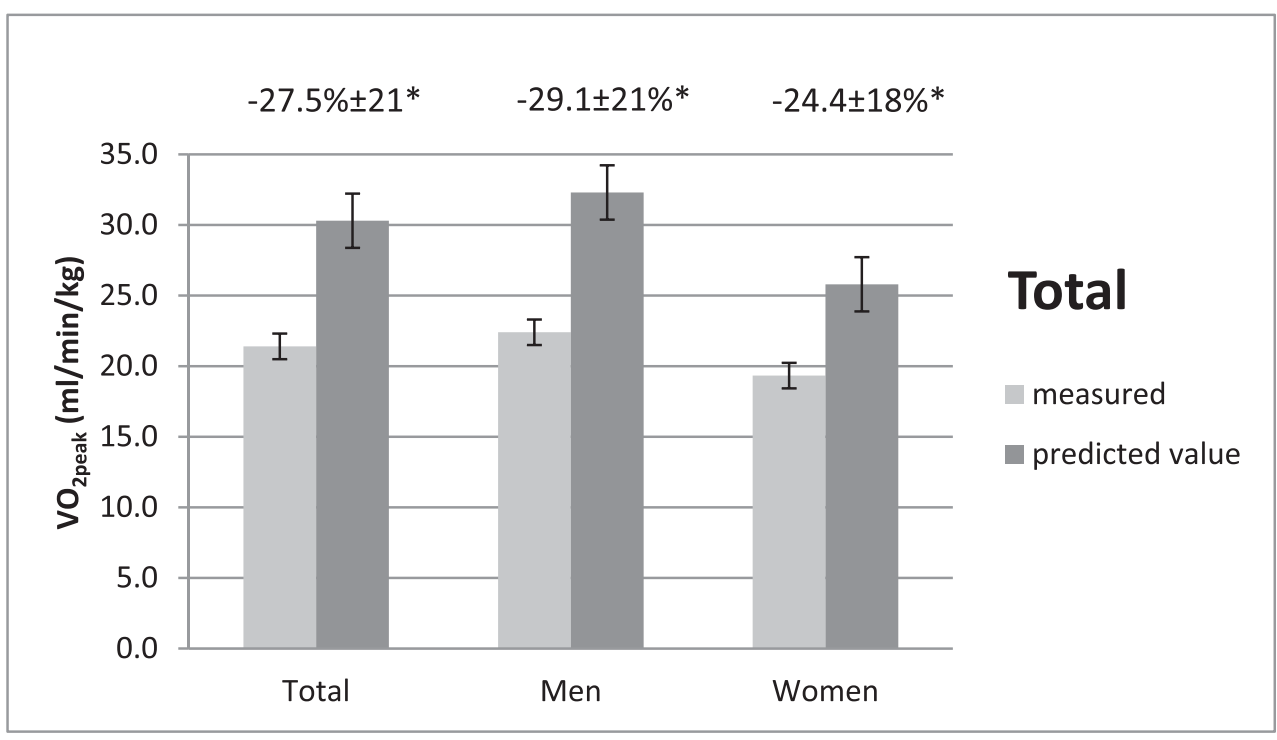

components of chemotherapies change intramuscular capillary density and mitochondrial content, and therefore reduce the oxygen extraction from the blood to the muscles, leading to reduced $\mathrm{VO}_{2 \text { peak }}$ values [28]. Causes of muscle dysfunction in cancer patients are complex and very little is known about adaptions at the muscle structural level [29]. However, improved muscle strength seems to have an impact on peak work rate in a CPET, but not on $\mathrm{VO}_{2 \text { peak }}$ in pancreatic cancer patients. This could also be explained by peripheral intramuscular changes and increase in cross-sectional areas of muscle fibers [30]. Further interpretations are difficult, because measures of muscle strength were not part of our present analysis. However, our data show that it may be worthwhile to carry out further investigations including measures of muscle strength.

Not unexpected, we showed that low levels of hemoglobin for at least 3 months prior to allo-HSCT were another predictive factor for low CRF. Reduced hemoglobin levels as a result of reduced bone marrow capacity due to the disease itself or chemotherapy treatment could limit oxygen delivery to exercising muscles and could affect CRF [31]. Low hemoglobin is associated with a lower quality of life and functional capacity [32] and is a prognostic factor for overall survival and disease-free survival in several hematological malignancies [33].

Further, gender had a significant impact on CRF. Women had lower $\mathrm{VO}_{2 \text { peak }}$ values than men, which is a well-known gender-related finding [34]. However, men showed slightly greater, but non-significant deviations, from heathy reference values than women $(-29.1 \%$ vs $-24.4 \%)$. This is not in line with findings of other comparable studies [8], but was similarly reported in solid cancer patients [19].

Regarding age, we found that patients between 46 and 55 years revealed reduced CRF, whereas the oldest age group (66-75 years) had the lowest deviation from healthy norm values. An explanation for this finding could be related to the fact that older patient groups mostly receive dosereduced therapies [35] compared with younger patients and therefore experience lower grades of myelosuppression and hematotoxicity. Otherwise, older cancer patients might be at increased risk of chemotherapy-related cardiotoxicity due to physiologic changes of several organ systems [36] or reduced tolerance of drug toxicity due to lower lean mass [37]. However, age- and treatment-associated variables are independently explaining variation in CRF and therefore seem to be both important for identifying patients with low CRF.

As expected, our data in both regression models show that physical inactivity prior to allo-HCT affects CRF negatively. In observational studies, it could be shown that a higher level of physical activity has a positive influence on the treatment process [38], which may additionally promote CRF even before allo-HSCT. Additionally, our models show that patients with higher BMI had a significantly lower CRF. This finding could be partially explained due to the fact that body weight is part of both formulas (BMI and $\mathrm{VO}_{2 \text { peak }} / \mathrm{ml} / \mathrm{min} / \mathrm{kg}$, respectively). Furthermore, the increased body mass also requires more oxygen during exercise, leading to reduced values. In allo-HSCT patients, both under- and overweight were associated with increased risk for complications and lower overall survival [39]. However, drawing conclusions from BMI regarding the association to CRF is difficult because the BMI gives no detailed information on the distribution of fat mass and muscle mass. In the field of allo-HSCT, for example, pretransplant weight loss has been shown to be a prognostic variable [40].

Based on our analyses, we were able to identify and characterize patients with low CRF prior to allo-HSCT. Past studies have shown that reduced CRF predicts symptom severity and mortality in patients undergoing allo-HSCT [8, 18]. Consequently, we recommend based on our data a targeted exercise program to create the best possible condition for 
Table 2 Comparison of measured $\mathrm{VO}_{2 \text { peak }}(\mathrm{ml} / \mathrm{kg} / \mathrm{min})$ values and the healthy gender-age-matched reference $\mathrm{VO}_{2 \text { peak }}$ values in total, $\mathrm{n} \_$Cardiotox, MET h/week

\begin{tabular}{|c|c|c|c|c|c|}
\hline Age group (years) & Number & $\begin{array}{l}\text { Deviation } \mathrm{VO}_{2 \text { peak }} \text { from } \\
\text { healthy reference }(\%)(\text { mean } \pm \mathrm{SD})\end{array}$ & $\begin{array}{l}\mathrm{VO}_{2 \text { peak }}(\mathrm{ml} / \mathrm{kg} / \mathrm{min}) \\
(\text { mean } \pm \mathrm{SD})\end{array}$ & n_Cardiotox $($ mean $\pm \mathrm{SD})$ & MET h/week $($ mean \pm SD) \\
\hline $18-35$ & 18 & $-25.1 \pm 15.7$ & $24.7 \pm 6.3$ & $1.9 \pm 1.3$ & $3.3 \pm 5.4(n=6)$ \\
\hline $36-45$ & 13 & $-31.7 \pm 18.7$ & $23.9 \pm 7.4$ & $1.5 \pm 1.4$ & $8.1 \pm 13.9(n=4)$ \\
\hline $46-55$ & 59 & $-36.6 \pm 16.7$ & $20.2 \pm 5.6$ & $1.7 \pm 1.4$ & $6.1 \pm 13.1(n=14)$ \\
\hline $56-65$ & 80 & $-25.4 \pm 22.9$ & $21.7 \pm 5.5$ & $1.4 \pm 1.2$ & $9.2 \pm 17.5(n=27)$ \\
\hline $66-75$ & 24 & $-11.8 \pm 15.9$ & $19.1 \pm 4.1$ & $0.9 \pm 1.9$ & $9.2 \pm 14.8(n=9)$ \\
\hline
\end{tabular}

$N$, number of patients; $M E T$, metabolic equivalent of task; HCT-CI, comorbidity index by Sorror

allo-HSCT. This would lead to a prehabilitation approach and is in line with current recommendations from the literature, "getting fit for allogeneic hematopoietic cell transplantation" [41]. Beneficial examples for prehabilitation in cancer patients exist [42, 43], but are totally understudied in hematological patients prior to allo-HSCT. Nevertheless, exercises have the potential to improve $\mathrm{CRF}$ in patients preparing to undergo HCT [23], which is potentially crucial for survival and for reducing treatment-related side effects $[44,45]$. Our data reinforce timely supportive care with exercise and identify needy subgroups in allo-HSCT candidates. For a better planning of exercise therapies, patients with low physical activity level, who are middle-aged, who have a high BMI, who had received cardio toxic agents, and who have chronic low hemoglobin levels should be the targeted population.

Our investigation has several limitations. The retrospective analysis was based on data of a randomized exercise intervention trial and therefore was not stratified and designed to evaluate baseline characteristics concerning potentially influencing factors with regard to $\mathrm{CRF}$ in patients prior to allo-HSCT. This might have also led to a preselection of a population with a potential affinity to exercise. Further, clinical data prior to allo-HSCT was

Table 3 Multiple regression of determinants $\mathrm{VO}_{2 \text { peak }}(\mathrm{ml} / \mathrm{min} / \mathrm{kg}) R^{2}=$ $40 \%, n=183$

\begin{tabular}{llll}
\hline & $\beta$ & $p$ & $95 \%$ CI \\
\hline Gender & -3.01 & 0.000 & $-4.44 ;-1.58$ \\
Age & -0.11 & 0.003 & $-0.17 ; 0.05$ \\
BMI & -0.44 & 0.000 & $-0.58 ;-0.31$ \\
t_Therapies & 0.11 & 0.146 & $-0.04 ; 0.27$ \\
n_Cardiotox & -0.73 & 0.015 & $-1.33 ;-0.11$ \\
HCT-CI & -0.34 & 0.138 & $-0.79 ; 0.11$ \\
Hemoglobin_auc & 0.56 & 0.004 & $0.18 ; 0.93$ \\
n__Transplantation- & 0.45 & 0.658 & $-0.89 ; 1.78$ \\
$\quad$ s & & & \\
Physical activity & 0.10 & 0.000 & $0.05 ;-0.14$ \\
\hline
\end{tabular}

$B M I$, body mass index; HCT-CI, comorbidity index by Sorror; $C I$, confidence interval extracted from the medical records which led to incomplete information.

This investigation also has several strengths. To our knowledge, the study sample of PETRA participant is currently the largest providing comprehensive cardiorespiratory fitness data applying gold standard assessment. Due to the large sample size, it was possible to identify influencing factors, which allow a more profound understanding of patients' performance status and its influencing parameters prior to allo-HSCT.

In conclusion, our findings demonstrated considerable reduction of CRF in patients immediately prior to allo-HSCT. We found that high BMI, low physical activity, amount of cardio toxic agents, and low hemoglobin level negatively impact CRF prior to allo-HSCT. Since CRF is proposed to be an independent risk factor for transplant outcome, strategies to modify CRF prior to allo-HSCT might be worthwhile to follow. Therefore, structured individualized aerobic exercise intervention programs should be recommended for increasing CRF prior to allo-HSCT. Based on our findings, describing risk factors for low CRF prior to allo-HSCT could lead to a targeted prehabilitative exercise intervention approach identifying those patients with highest needs.

Table 4 Multiple regression of determinants deviation $\mathrm{VO}_{2 \text { peak }}(\mathrm{ml} /$ $\mathrm{min} / \mathrm{kg}$ ) from healthy reference (\%) $R^{2}=26 \%, n=183$

\begin{tabular}{llll}
\hline & $\beta$ & $p$ & $95 \%$ CI \\
\hline Gender & 7.58 & 0.001 & $1.72 ; 13.43$ \\
Age & 0.043 & 0.000 & $0.19 ; 0.67$ \\
BMI & -1.12 & 0.000 & $-1.68 ;-0.57$ \\
t_Therapies & 0.13 & 0.673 & $-0.48 ; 0.75$ \\
n_Cardiotox & -2.46 & 0.047 & $-4.89 ;-0.36$ \\
HCT-CI & -0.30 & 0.750 & $-2.15 ; 1.55$ \\
Hemoglobin_auc & 1.99 & 0.001 & $0.46 ; 3.52$ \\
n__Cransplantation- & 1.56 & 0.575 & $-3.91 ; 7.02$ \\
$\quad$ & & & \\
Physical activity & 0.41 & 0.000 & $0.22 ; 0.60$ \\
\hline
\end{tabular}

$B M I$, body mass index; HCT-CI, comorbidity index by Sorror; $C I$, confidence interval 
Authors' contributions Conception and design: Joachim Wiskemann, Martin Bohus

Provision of study materials or patients: Joachim Wiskemann, Rea Kühl, Matthias Limbach, Peter Dreger, Birgit Friedmann-Bette, Friederike Rosenberger, Thomas Luft, Andrea Bondong

Collection and assembly of data: Rea Kühl, Matthias Limbach

Statistical analyses and interpretation of the data: Joachim

Wiskemann, Matthias Limbach, Nikolaus Kleindienst, Friederike

Rosenberger, Rea Kühl

Drafted and finalized the manuscript: All authors

Funding information Open Access funding provided by Projekt DEAL. This work was supported by the Deutsche José Carreras Leukämie Stiftung e.V. (project no. R10/42pf and R13/27).

Availability of data and material Not applicable

\section{Compliance with ethical standards}

Conflict of interests The authors declare that they have no conflict of interest.

Ethical approval The study has been approved by the ethics committees of the Ethics Committee II of the University of Mannheim (number 2009-349 N-MA) and the Ethics Committee of the University of Heidelberg (number S-021/2011), and is registered at ClinicalTrials.gov (NCT01374399).

Consent to participate All patients provide written informed consent

Consent for publication All patients provide written informed consent.

Code availability Not applicable

Open Access This article is licensed under a Creative Commons Attribution 4.0 International License, which permits use, sharing, adaptation, distribution and reproduction in any medium or format, as long as you give appropriate credit to the original author(s) and the source, provide a link to the Creative Commons licence, and indicate if changes were made. The images or other third party material in this article are included in the article's Creative Commons licence, unless indicated otherwise in a credit line to the material. If material is not included in the article's Creative Commons licence and your intended use is not permitted by statutory regulation or exceeds the permitted use, you will need to obtain permission directly from the copyright holder. To view a copy of this licence, visit http://creativecommons.org/licenses/by/4.0/.

\section{References}

1. Passweg JR, Baldomero H, Bader P, Bonini C, Cesaro S, Dreger P, Duarte RF, Dufour C, Kuball J, Farge-Bancel D, Gennery A, Kroger N, Lanza F, Nagler A, Sureda A, Mohty M (2016) Hematopoietic stem cell transplantation in Europe 2014: more than 40000 transplants annually. Bone Marrow Transplant 51:786-792. https://doi.org/10.1038/bmt.2016.20

2. Henig I, Zuckerman T (2014) Hematopoietic stem cell transplantation50 years of evolution and future perspectives. Rambam Maimonides Med J 5:e028. https://doi.org/10.5041/rmmj.10162

3. Gooley TA, Chien JW, Pergam SA, Hingorani S, Sorror ML, Boeckh M, Martin PJ, Sandmaier BM, Marr KA, Appelbaum FR,
Storb R, McDonald GB (2010) Reduced mortality after allogeneic hematopoietic-cell transplantation. N Engl J Med 363:2091-2101. https://doi.org/10.1056/NEJMoa1004383

4. Sorror M, Storer B, Sandmaier BM, Maloney DG, Chauncey TR, Langston A, Maziarz RT, Pulsipher M, McSweeney PA, Storb R (2008) Hematopoietic cell transplantation-comorbidity index and Karnofsky performance status are independent predictors of morbidity and mortality after allogeneic nonmyeloablative hematopoietic cell transplantation. Cancer 112:1992-2001

5. Elsawy M, Sorror ML (2016) Up-to-date tools for risk assessment before allogeneic hematopoietic cell transplantation. Bone Marrow Transplant 51:1283-1300. https://doi.org/10.1038/bmt.2016.141

6. Gratwohl A (2012) The EBMT risk score. Bone Marrow Transplant 47:749-756. https://doi.org/10.1038/bmt.2011.110

7. Kelsey CR, Scott JM, Lane A, Schwitzer E, West MJ, Thomas S, Herndon JE 2nd, Michalski MG, Horwitz ME, Hennig T, Jones LW (2014) Cardiopulmonary exercise testing prior to myeloablative allo-SCT: a feasibility study. Bone Marrow Transplant 49:1330 1336. https://doi.org/10.1038/bmt.2014.159

8. Wood WA, Deal AM, Reeve BB, Abernethy AP, Basch E, Mitchell SA, Shatten C, Hie Kim Y, Whitley J, Serody JS, Shea T, Battaglini C (2013) Cardiopulmonary fitness in patients undergoing hematopoietic SCT: a pilot study. Bone Marrow Transplant 48:1342-1349. https://doi.org/10.1038/bmt.2013.58

9. Jones LW, Courneya KS, Mackey JR, Muss HB, Pituskin EN, Scott JM, Hornsby WE, Coan AD, Herndon JE 2nd, Douglas PS, Haykowsky M (2012) Cardiopulmonary function and age-related decline across the breast cancer survivorship continuum. J Clin Oncol 30:2530-2537. https://doi.org/10.1200/JCO.2011.39.9014

10. Jones LW, Watson D, Herndon JE 2nd, Eves ND, Haithcock BE, Loewen G, Kohman L (2010) Peak oxygen consumption and longterm all-cause mortality in nonsmall cell lung cancer. Cancer 116: 4825-4832. https://doi.org/10.1002/cncr.25396

11. American Thoracic S, American College of Chest P (2003) ATS/ ACCP Statement on cardiopulmonary exercise testing. Am J Respir Crit Care Med 167:211-277. https://doi.org/10.1164/rccm.167.2. 211

12. Kuehl R, Schmidt ME, Dreger P, Steindorf K, Bohus M, Wiskemann J (2016) Determinants of exercise adherence and contamination in a randomized controlled trial in cancer patients during and after allogeneic HCT. Support Care Cancer 24:4327-4337. https://doi.org/10.1007/s00520-016-3271-6

13. Sorror ML (2013) How I assess comorbidities before hematopoietic cell transplantation. Blood 121:2854-2863. https://doi.org/10. 1182/blood-2012-09-455063

14. Koch B, Schaper C, Ittermann T, Spielhagen T, Dorr M, Volzke H, Opitz CF, Ewert R, Glaser S (2009) Reference values for cardiopulmonary exercise testing in healthy volunteers: the SHIP study. Eur Respir J 33:389-397. https://doi.org/10.1183/09031936. 00074208

15. Duh MS, Lefebvre P, Fastenau J, Piech CT, Waltzman RJ (2005) Assessing the clinical benefits of erythropoietic agents using area under the hemoglobin change curve. Oncologist 10:438-448. https://doi.org/10.1634/theoncologist.10-6-438

16. Morishita S, Kaida K, Ikegame K, Yoshihara S, Taniguchi K, Okada M, Kodama N, Ogawa H, Domen K (2012) Impaired physiological function and health-related QOL in patients before hematopoietic stem-cell transplantation. Support Care Cancer 20:821829. https://doi.org/10.1007/s00520-011-1156-2

17. White AC, Terrin N, Miller KB, Ryan HF (2005) Impaired respiratory and skeletal muscle strength in patients prior to hematopoietic stem-cell transplantation. Chest 128:145-152

18. Jones LW, Devlin SM, Maloy MA, Wood WA, Tuohy S, Espiritu N, Aquino J, Kendig T, Michalski MG, Gyurkocza B, Schaffer WL, Ali B, Giralt S, Jakubowski AA (2015) Prognostic importance of pretransplant functional capacity after allogeneic hematopoietic cell 
transplantation. Oncologist https://doi.org/10.1634/theoncologist. 2015-0200

19. Clauss D, Tjaden C, Hackert T, Schneider L, Ulrich CM, Wiskemann J, Steindorf K (2017) Cardiorespiratory fitness and muscle strength in pancreatic cancer patients. Support Care Cancer 25:2797-2807. https://doi.org/10.1007/s00520-017-36948

20. Klassen O, Schmidt ME, Scharhag-Rosenberger F, Sorkin M, Ulrich CM, Schneeweiss A, Potthoff K, Steindorf K, Wiskemann J (2014) Cardiorespiratory fitness in breast cancer patients undergoing adjuvant therapy. Acta Oncol 53:1356-1365. https://doi.org/ 10.3109/0284186X.2014.899435

21. Scott JM, Zabor EC, Schwitzer E, Koelwyn GJ, Adams SC, Nilsen TS, Moskowitz CS, Matsoukas K, Iyengar NM, Dang CT, Jones LW (2018) Efficacy of exercise therapy on cardiorespiratory fitness in patients with cancer: a systematic review and meta-analysis. $\mathrm{J}$ Clin Oncol 36:2297-2305. https://doi.org/10.1200/JCO.2017.77. 5809

22. Persoon S, Kersten MJ, van der Weiden K, Buffart LM, Nollet F, Brug J, Chinapaw MJ (2013) Effects of exercise in patients treated with stem cell transplantation for a hematologic malignancy: a systematic review and meta-analysis. Cancer Treat Rev 39:682-690. https://doi.org/10.1016/j.ctrv.2013.01.001

23. Wood WA, Phillips B, Smith-Ryan AE, Wilson D, Deal AM, Bailey C, Meeneghan M, Reeve BB, Basch EM, Bennett AV, Shea TC, Battaglini CL (2016) Personalized home-based interval exercise training may improve cardiorespiratory fitness in cancer patients preparing to undergo hematopoietic cell transplantation. Bone Marrow Transplant 51:967-972. https://doi.org/10.1038/bmt. 2016.73

24. Yeh ET, Tong AT, Lenihan DJ, Yusuf SW, Swafford J, Champion C, Durand JB, Gibbs H, Zafarmand AA, Ewer MS (2004) Cardiovascular complications of cancer therapy: diagnosis, pathogenesis, and management. Circulation 109:3122-3131. https://doi. org/10.1161/01.CIR.0000133187.74800.B9

25. Stellitano A, Fedele R, Barilla S, Iaria A, Rao CM, Martino M (2017) Chemotherapy and cardiotoxicity in hematologic malignancies. Curr Cancer Drug Targets 17:311-324. https://doi.org/10. 2174/1568009617666161121141607

26. Scott JM, Nilsen TS, Gupta D, Jones LW (2018) Exercise therapy and cardiovascular toxicity in cancer. Circulation 137:1176-1191. https://doi.org/10.1161/CIRCULATIONAHA.117.024671

27. Plana JC, Galderisi M, Barac A, Ewer MS, Ky B, Scherrer-Crosbie M, Ganame J, Sebag IA, Agler DA, Badano LP, Banchs J, Cardinale D, Carver J, Cerqueira M, JM DC, Edvardsen T, Flamm SD, Force T, Griffin BP, Jerusalem G, Liu JE, Magalhaes A, Marwick T, Sanchez LY, Sicari R, Villarraga HR, Lancellotti P (2014) Expert consensus for multimodality imaging evaluation of adult patients during and after cancer therapy: a report from the American Society of Echocardiography and the European Association of Cardiovascular Imaging. J Am Soc Echocardiogr 27:911-939. https://doi.org/10.1016/j.echo.2014.07.012

28. Christensen JF, Simonsen C, Hojman P (2018) Exercise Training in Cancer Control and Treatment. Compr Physiol 9:165-205. https:// doi.org/10.1002/cphy.c180016

29. Christensen JF, Jones LW, Andersen JL, Daugaard G, Rorth M, Hojman P (2014) Muscle dysfunction in cancer patients. Ann Oncol 25:947-958. https://doi.org/10.1093/annonc/mdt551

30. Wiskemann J, Clauss D, Tjaden C, Hackert T, Schneider L, Ulrich CM, Steindorf K (2019) Progressive resistance training to impact physical fitness and body weight in pancreatic cancer patients: a randomized controlled trial. Pancreas 48:257-266. https://doi.org/ 10.1097/MPA.0000000000001221
31. Calbet JA, Lundby C, Koskolou M, Boushel R (2006) Importance of hemoglobin concentration to exercise: acute manipulations. Respir Physiol Neurobiol 151:132-140. https://doi.org/10.1016/j. resp.2006.01.014

32. Groopman JE, Itri LM (1999) Chemotherapy-induced anemia in adults: incidence and treatment. J Natl Cancer Inst 91:1616-1634

33. Van Belle SJP (2004) What is the value of hemoglobin as a prognostic and predictive factor in cancer? Eur J Cancer Suppl 2:11-19. https://doi.org/10.1016/s1359-6349(03)00103-4

34. Hutchinson PL, Cureton KJ, Outz H, Wilson G (1991) Relationship of cardiac size to maximal oxygen uptake and body size in men and women. Int J Sports Med 12:369-373. https://doi.org/10.1055/s2007-1024696

35. Erba HP (2015) Finding the optimal combination therapy for the treatment of newly diagnosed AML in older patients unfit for intensive therapy. Leuk Res 39:183-191. https://doi.org/10.1016/j. leukres.2014.11.027

36. Carreca I, Balducci L, Extermann M (2005) Cancer in the older person. Cancer Treat Rev 31:380-402. https://doi.org/10.1016/j. ctrv.2005.04.012

37. Hopkins JJ, Sawyer MB (2017) A review of body composition and pharmacokinetics in oncology. Expert Rev Clin Pharmacol 10:947956. https://doi.org/10.1080/17512433.2017.1347503

38. Schmid D, Behrens G, Arem H, Hart C, Herr W, Jochem C, Matthews CE, Leitzmann MF (2018) Pre- and post-diagnosis physical activity, television viewing, and mortality among hematologic cancer survivors. PLoS One 13:e0192078. https://doi.org/10.1371/ journal.pone. 0192078

39. Urbain P, Birlinger J, Ihorst G, Biesalski HK, Finke J, Bertz H (2013) Body mass index and bioelectrical impedance phase angle as potentially modifiable nutritional markers are independent risk factors for outcome in allogeneic hematopoietic cell transplantation. Ann Hematol 92:111-119. https://doi.org/10.1007/s00277-012$1573-4$

40. Radujkovic A, Becker N, Benner A, Penack O, Platzbecker U, Stolzel F, Bornhauser M, Hegenbart U, Ho AD, Dreger P, Luft T (2015) Pre-transplant weight loss predicts inferior outcome after allogeneic stem cell transplantation in patients with myelodysplastic syndrome. Oncotarget

41. Wood WA (2014) Getting fit for allogeneic hematopoietic cell transplantation. Bone Marrow Transplant 49:1249-1250. https:// doi.org/10.1038/bmt.2014.160

42. Rosero ID, Ramirez-Velez R, Lucia A, Martinez-Velilla N, SantosLozano A, Valenzuela PL, Morilla I, Izquierdo M (2019) Systematic review and meta-analysis of randomized, controlled trials on preoperative physical exercise interventions in patients with non-small-cell lung cancer. Cancers 11 https://doi.org/10.3390/ cancers11070944

43. Bhatia C, Kayser B (2019) Preoperative high-intensity interval training is effective and safe in deconditioned patients with lung cancer: a randomized clinical trial. J Rehabil Med. https://doi.org/ $10.2340 / 16501977-2592$

44. Cormie P, Zopf EM, Zhang X, Schmitz KH (2017) The impact of exercise on cancer mortality, recurrence, and treatment-related adverse effects. Epidemiol Rev 39:71-92. https://doi.org/10.1093/ epirev/mxx007

45. Wiskemann J, Kleindienst N, Kuehl R, Dreger P, Schwerdtfeger R, Bohus M (2015) Effects of physical exercise on survival after allogeneic stem cell transplantation. Int J Cancer 137:2749-2756. https://doi.org/10.1002/ijc.29633

Publisher's note Springer Nature remains neutral with regard to jurisdictional claims in published maps and institutional affiliations. 